\title{
DO CHANGES IN ANAL SPHINCTER ANATOMY CORRELATE WITH ANAL FUNCTION IN WOMEN WITH A HISTORY OF VAGINAL DELIVERY?
}

\author{
Sthela Maria MURAD-REGADAS ${ }^{1,2}$, Iris Daiana DEALCANFREITAS ${ }^{1}$, \\ Francisco Sergio Pinheiro REGADAS ${ }^{1}$, Lusmar Veras RODRIGUES ${ }^{1,2}$, \\ Graziela Olivia da Silva FERNANDES ${ }^{1}$ and Jacyara de Jesus Rosa PEREIRA ${ }^{1}$
}

\begin{abstract}
Objectives - To evaluate anal sphincter anatomy using three-dimensional ultrasonography (3-DAUS) in incontinent women with vaginal delivery, correlate anatomical findings with symptoms of fecal incontinence and determine the effect of vaginal delivery on anal canal anatomy and function. Methods - Female with fecal incontinence and vaginal delivery were assessed with Wexner's score, manometry, and 3DAUS. A control group comprising asymptomatic nulliparous was included. Anal pressure, the angle of the defect and length of the external anal sphincter (EAS), the anterior and posterior internal anal sphincter (IAS), the EAS + puborectal and the gap were measured and correlated with score. Results - Of the 62, 49 had fecal incontinence and 13 were asymptomatic. Twenty five had EAS defects, 8 had combined EAS+IAS defects, 16 had intact sphincters and continence scores were similar. Subjects with sphincter defects had a shorter anterior EAS, IAS and longer gap than women without defects. Those with a vaginal delivery and intact sphincters had a shorter anterior EAS and longer gap than nulliparous. We found correlations between resting pressure and anterior EAS and IAS length in patients with defects. Conclusions - Fecal incontinence symptoms did not correlate with anal pressures and anal sphincter anatomy changes, but women with sphincter defects have shorter anterior EAS and IAS and a longer gap.
\end{abstract}

HEADINGS - Fecal incontinence, ultrasonography. Anal canal, physiology. Natural childbirth.

\section{INTRODUCTION}

Fecal incontinence has been reported to affect up to $12 \%$ of the population. It has a significant impact on daily life and can lead to social isolation ${ }^{(11)}$.

Different risk categories for fecal incontinence have been described ${ }^{(12)}$. Females with a history of previous vaginal delivery make up the majority of affected individuals $^{(20)}$, but age, BMI, previous anal and colorectal surgery, radiation exposure, and neurological conditions are also risk factors ${ }^{(12)}$. Therefore, proper evaluation of this condition-including use of fecal incontinence scores to quantify subjective symptoms and functional and anatomic measurements-plays a key role in patient management.

Anal ultrasonography is a well-established method for identification of sphincter defects, and correlates well with surgical findings ${ }^{(3,10)}$. Recent advances in technology and the advent of three-dimensional ultrasonography have enabled multiplanar study of anal canal anatomy and measurement of the length and volume of the anal canal muscles ${ }^{(22,27)}$. Although some studies have reported poor correlation between symptoms, anal manometry pressures, and ultrasound measurements ${ }^{(4,5,22)}$, both studies should be offered to symptomatic patients ${ }^{(2)}$. A wide range of treatment modalities is available, including biofeedback, surgical sphincter repair, sacral nerve stimulation, and the artificial bowel sphincter, and a comprehensive assessment is required to identify anatomic and functional changes and inform the choice for the best treatment option. Within this context, this study was designed to evaluate anal sphincter anatomy using three-dimensional ultrasonography (3-DAUS) in a group of incontinent women with a history of vaginal delivery, correlate anatomical findings with symptoms of fecal incontinence and sphincter function, and determine the effect of vaginal delivery on anal

Declared conflict of interest of all authors: none

${ }^{1}$ Departamento de Cirurgia, Faculdade de Medicina da Universidade Federal do Ceará. ${ }^{2}$ Departamento de Fisiologia Anorretal e Assoalho Pélvico, Hospital das Clínicas, Universidade Federal do Ceará, Brasil.

Correspondence: Sthela M. Murad-Regadas. R. Atilano de Moura, 430, ap. 200. CEP 60810-180 - Fortaleza, CE, Brasil. Email: smregadas@hospitalsaocarlos.com.br 
canal anatomy. The secondary objective was to determine the interobserver reliability of 3-DAUS for measurement of anal canal structures.

\section{METHODS}

\section{Patients}

Consecutive female patients who presented to the Walter Cantídio University Hospital of the Federal University of Ceará, Brazil, between January 2012 and December 2012, with symptoms of fecal incontinence and a history of previous vaginal delivery were considered eligible for the study. All were assessed by means of Wexner's continence score, anal manometry, and 3-DAUS. Patients were then allocated into groups according to the absence or presence of sphincter ani defects.

Patients with inflammatory bowel disease, HIV infection, obesity, diabetes, neurologic disorders, or symptoms of stress and urge urinary incontinence were excluded, as were patients with a history of previous colorectal, anorectal, or gynecological surgery. Patients with full-length defects of the external anal sphincter (EAS) and internal anal sphincter (IAS) were also excluded.

The clinical protocol was approved by the Walter Cantídio University Hospital Research Ethics Committee, and all patients provided written informed consent.

\section{Control group}

A control group comprising 13 asymptomatic nulliparous women was recruited through the outpatient Colorectal Surgery and Gynecology clinics of the Walter Cantídio University Hospital. The exclusion criteria were the same as for the patient group.

\section{Assessments}

- Incontinence severity

Fecal incontinence was assessed by means of the Wexner score (Cleveland Clinic Florida Incontinence Scale) at the time of the visit ${ }^{(7)}$. The continence grading scale addresses leakage of gas, liquid, solid stool, need to wear pad, and lifestyle changes at varying frequencies and the extent to which they affect the patient's life.

\section{- Anorectal manometry}

Anorectal manometry was performed in the incontinent group. A flexible, water-perfused polyethylene catheter and an 8-channel manometer were used with ProctoMaster software (DynaMed, São Paulo, Brazil) to calculate anal canal pressure at rest, maximum anal squeeze pressure, and capacity required to sustain squeeze pressure for 30 seconds.

All evaluations of manometric data were performed by the same examiner.

\section{-Three-dimensional anal ultrasonography}

3-DAUS was performed in the incontinent and control groups during a one-time visit. After administration of a rectal enema (completed 2 hours before scanning), patients were placed in the left lateral position for examination. After digital rectal examination, the endoprobe was introduced as far as the upper anal canal. A 3D ultrasound endoprobe (Pro-Focus 2052; 9-16 MHz; focal distance 2.8-6.2 cm; BK Medical, Herlev, Denmark) was used. Images up to $6.0 \mathrm{~cm}$ long were captured along the proximal-distal axis for up to 55 seconds by moving two crystals (axial and longitudinal) on the extremity of the transducer automatically, without moving the probe. The examination involved a series of transaxial slices up to $0.20 \mathrm{~mm}$ thick to produce a high-resolution digitalized volumetric image. Volume was displayed as a $3 \mathrm{D}$ cube image and recorded and analyzed in multiple planes.

The ultrasound identified the presence of a sphincter defect, combined EAS and IAS defects or if the lesion involved the EAS alone. Measurements obtained included the following: length of the anterior EAS and radial angle of the anterior EAS defect, length of the anterior and posterior internal anal sphincter IAS, length of the posterior EAS plus the puborectalis muscle (EAS+PR), and the gap length (distance from the proximal edge of the posterior PR to the proximal edge of the anterior EAS, corresponding to the area in the anterior quadrant without striated muscle) were measured and correlated with incontinence score. Groups were also compared with regard to sphincter muscle length and anal pressure.

The examination was performed by a single colorectal surgeon with experience in 3-DAUS (S.M.M.R.).

To determine interobserver variability in 3-DAUS measurements of the anal sphincters, all images (entire 3D cubes) were numbered randomly and then reassessed and measured independently by two blinded surgeons (S.M.M.R and G.O.S.F.). Interobserver agreement was assessed in a sample of 26 study participants that included both incontinent patients and controls.

\section{Statistical analysis}

The incontinent groups were compared with regard to the lengths of the anal sphincters and anal pressures. A subgroup composed of all incontinent patients without a sphincter defect was also compared with the control group. Differences between groups were assessed by means of the Student $t$ test and 1-way ANOVA for continuous data. The chi-square test was used to compare groups with regard to mode of delivery and presence of fecal incontinence symptoms. The significance level was set at $P<0.05$.

The relationship between continence scores and anal pressures and the lengths of the anal sphincters were evaluated by calculation of Spearman rank correlation coefficients $(\rho)$.

Interobserver agreement was assessed by calculation of intraclass correlation coefficients with $95 \%$ confidence intervals. The strength of agreement was interpreted according to the Altman classification system $(<0.20$, poor; $0.21-0.40$, fair; $0.41-0.60$, moderate; $0.61-0.80$, good; $0.81-1.00$, very good) $)^{(1)}$.

Data were analyzed using SPSS 14.0 for Windows (IBMSPSS Inc., Chicago, IL) 


\section{RESULTS}

\section{Patient characteristics}

Of the 62 women included in the study, 49 had symptoms of fecal incontinence and 13 were asymptomatic nulliparous volunteers. The mean age of the incontinent patients was 57 (SD, 10.8; range, 34-72) years. The mean age of the control group was 48 (SD, 13.8; range, 30-68) years.

Of these 49 women with fecal incontinence, $25(51 \%)$ had EAS defects, $8(16 \%)$ had combined EAS and IAS defects and $16(33 \%)$ had intact sphincters. The EAS defect angle ranged from 104 to 166 (mean, 141; SD, 15.5) degrees (Figure 1, 2).
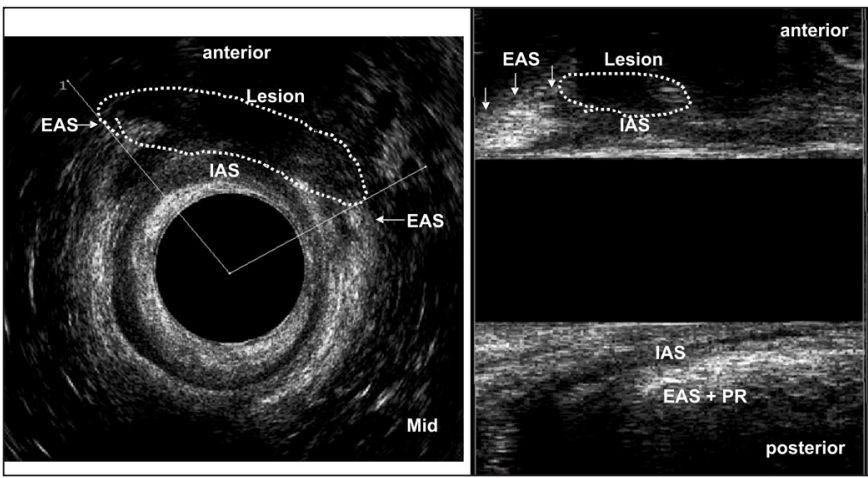

FIGURE 1. External anal sphincter defect after vaginal delivery

(A) Mid anal canal. The EAS defect angle (axial plane). (B) Measurements of the lengths of the residual EAS (arrows). IAS is intact (sagittal plane). EAS: external anal sphincter; IAS: internal anal sphincter; EAS +PR external anal sphincter plus puborectalis muscle

\section{CCF continence Score}

As noted in Table 1, continence scores were similar in patients with and without sphincter defects.
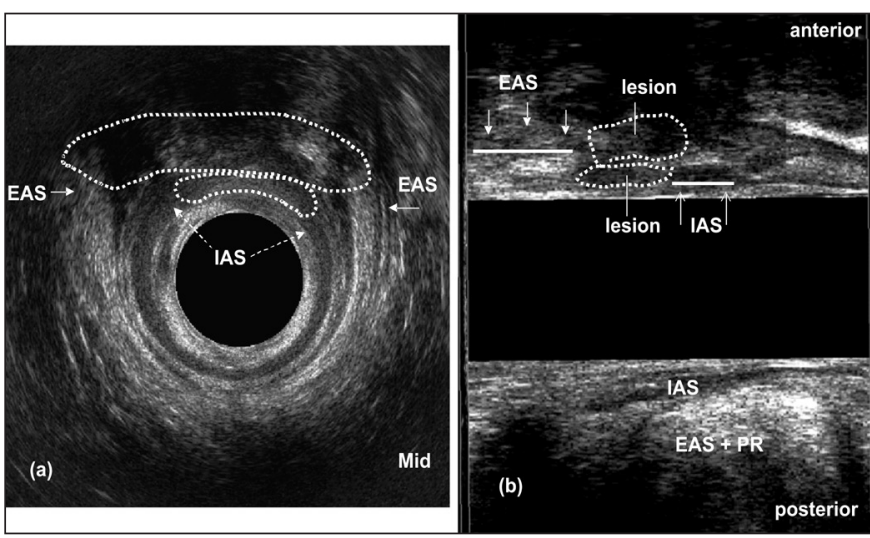

FIGURE 2. Combined EAS and IAS defect after vaginal delivery (A) Mid anal canal. The EAS and IAS defects (axial plane). (B) Measurements of the lengths of the residual EAS and IAS (arrows) (sagittal plane). EAS: external anal sphincter; IAS: internal anal sphincter; EAS+PR: external anal sphincter plus puborectalis muscle

\section{Anorectal manometry}

We did not find a statistically significant difference in resting and maximum squeeze pressure between patients with and without sphincter defects, but patients with intact sphincters had a significantly higher 30 -s voluntary squeeze pressure (Table 1).

\section{Sphincter lengths measured by 3-DAUS}

Subjects with sphincter defects had a significantly shorter anterior EAS and IAS and longer gap than women without any defects. Those with a history of vaginal delivery and intact sphincters had a significantly shorter anterior EAS and longer gap than nulliparous subjects (Table 2) (Figure 3).

TABLE 1. Incontinent women with previous vaginal delivery and asymptomatic nulliparous volunteers: data

\begin{tabular}{lcccc}
\hline Variables & $\begin{array}{c}\text { EAS defect } \\
(\mathrm{n}=25) \text { mean }( \pm)\end{array}$ & $\begin{array}{c}\text { EAS/IAS defect } \\
(\mathbf{n}=08) \text { mean }( \pm)\end{array}$ & $\begin{array}{c}\text { Intact sphincter } \\
(\mathbf{n}=16) \text { mean }( \pm)\end{array}$ & $\begin{array}{c}\text { Nulliparous } \\
(\mathbf{n}=13)\end{array}$ \\
\hline Age & $58(12.96)$ & $59(4.79)$ & $55(10.74)$ & $48(13.85)$ \\
Incontinence score & $4(3.68)$ & $6(5.62)$ & $4(3.94)$ & 0 \\
Resting pressure $(\mathrm{mmHg})$ & $37(3.51)$ & $25(4.08)$ & $37(3.82)$ & - \\
Maximum squeeze pressure $(\mathrm{mmHg})$ & $95(10.42)$ & $80(13.83)$ & $105(10.72)$ & - \\
Squeeze pressure for 30 s* $(\mathrm{mmHg})$ & $59(7.81)$ & $55(9.83)$ & $82(7.28)$ & - \\
\hline
\end{tabular}

$* P<0.05$; EAS: external anal sphincter; IAS: internal anal sphincter

TABLE 2. 3-Dimensional anal ultrasonography measurements in incontinent women with previous vaginal delivery and asymptomatic nulliparous volunteers

\begin{tabular}{lcccc}
\hline Variables & $\begin{array}{c}\text { EAS defect }(\mathbf{n}=25) \\
\text { mean }( \pm)\end{array}$ & $\begin{array}{c}\text { EAS/IAS defect } \\
(\mathbf{n}=08) \text { mean }( \pm)\end{array}$ & $\begin{array}{c}\text { Intact sphincter } \\
(\mathbf{n}=16) \text { mean }( \pm)\end{array}$ & $\begin{array}{c}\text { Nulliparous } \\
(\mathbf{n}=13)\end{array}$ \\
\hline Anterior EAS* $(\mathrm{cm})$ & $1.1(0.13)$ & $0.9(0.11)$ & $1.6(0.12)$ & $1.8(0.22)$ \\
Anterior IAS $(\mathrm{cm})$ & $2.4(0.35)$ & $1.2(0.09)$ & $2.7(0.08)$ & $2.5(0.33)$ \\
Gap length* $(\mathrm{cm})$ & $2.6(0.48)$ & $2.5(0.31)$ & $2.2(0.51)$ & $1.8(0.42)$ \\
Posterior IAS $(\mathrm{cm})$ & $3.1(0.36)$ & $3.0(0.14)$ & $3.3(0.38)$ & $3.2(0.51)$ \\
Posterior EAS+PR $(\mathrm{cm})$ & $3.2(0.38)$ & $3.0(0.10)$ & $3.3(0.38)$ & $3.2(0.51)$ \\
Radial angle of the defect & $141.9(15.59)$ & $136(14.93)$ & - & - \\
\hline
\end{tabular}

$* P<0.05$; EAS: external anal sphincter; IAS: internal anal sphincter; PR: puborectal 

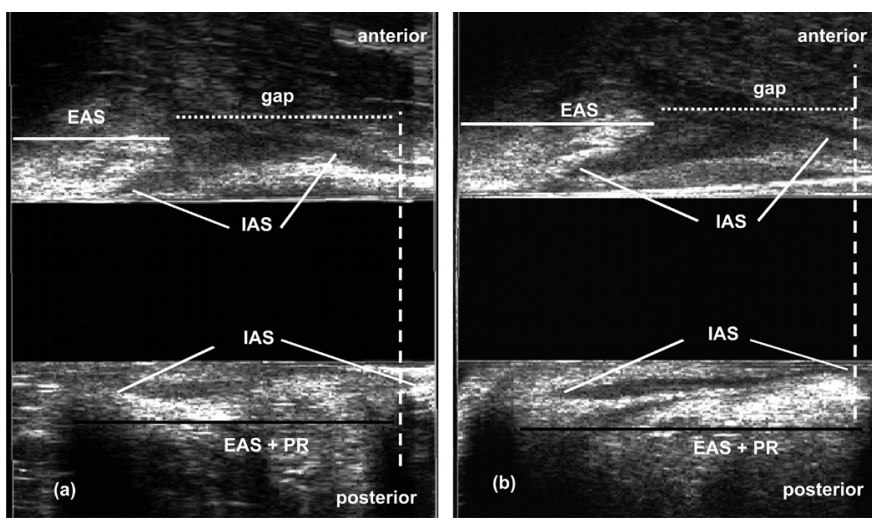

FIGURE 3. Measurements of sphincter lengths by 3-Dimensional anal ultrasonography (sagittal plane).

(A) Patients with previous vaginal delivery and intact sphincters (sagittal plane). (B) Nulliparous voluntary (sagittal plane).

EAS: external anal sphincter; IAS: internal anal sphincter; EAS $+P R$ : external anal sphincter plus puborectalis muscle

There were no significant differences in length of the posterior internal anal sphincter or length of the posterior EAS plus the puborectalis muscle among women with sphincter defects, women with intact sphincters, and controls (Table 2).

\section{Correlation between CCF continence scores and anorectal manometry findings}

We found no correlation between continence scores and anorectal manometry pressures in patients with sphincter defects (EAS defect plus combined EAS and IAS defects) or those with intact sphincters (Table 3).

\section{Correlation between CCF continence scores and Sphincter Lengths Measured by 3-DAUS}

We did not observe any correlation between 3-DAUS measurements (anterior EAS, IAS and gap length and the radial angle of the defect) and continence scores in patients with sphincter defects (EAS defect plus combined EAS and IAS defects) or those with intact sphincters (Table 4).

\section{Correlation between sphincter lengths measured by 3-DAUS and anorectal manometry}

We found no correlation between anorectal manometry pressures and anterior EAS and IAS length on 3-DAUS in patients with intact sphincters. There were positive correlations between resting pressure and anterior EAS and IAS length on 3-DAUS in patients with sphincter defects (EAS defect plus combined EAS and IAS defects), but we did not observe any correlation between maximum squeeze pressure

TABLE 3. Correlation between continence scores and anal pressure measurements on anorectal manometry in patients had sphincter defects (EAS defect plus combined EAS and IAS defects) and had intact sphincters

\begin{tabular}{lcc}
\hline Anorectal manometry & r (95\% confidence interval) & $P$ \\
\hline EAS defect plus EAS + IAS defect $(\mathrm{n}=33)$ Continence score vs & & $-0.383(-0.682$ to 0.026$)$ \\
$\quad$ Resting pressure $(\mathrm{mmHg})$ & $-0.174(-0.541$ to 0.248$)$ & 0.0587 \\
Maximum squeeze pressure $(\mathrm{mmHg})$ & $-0.108(-0.525$ to 0.351$)$ & 0.4038 \\
CSqueeze Pressure for $30 \mathrm{~s}(\mathrm{mmHg})$ & $-0.077(-0.595$ to 0.486$)$ & 0.7929 \\
Intact sphincter $(\mathrm{n}=16)$ Continence score vs & $-0.512(-0.825$ to 0.042$)$ & 0.0610 \\
Resting pressure $(\mathrm{mmHg})$ & $0.024(-0.525$ to 0.560$)$ & 0.9331 \\
Maximum squeeze pressure $(\mathrm{mmHg})$ & \\
Squeeze pressure for $30 \mathrm{~s}(\mathrm{mmHg})$ & &
\end{tabular}

EAS: external anal sphincter; IAS: internal anal sphincter

TABLE 4. Correlation between continence scores and sphincter lengths measured by 3-DAUS in patients had sphincter defects (EAS defect plus combined EAS and IAS defects) and had intact sphincters.

\begin{tabular}{lcc}
\hline Dimensional anal ultrasonography & r (95\% confidence interval) & $P$ \\
\hline EAS defect plus EAS +IAS defect $(\mathrm{n}=33)$ Continence score vs & & 0.1426 \\
Anterior EAS $(\mathrm{cm})$ & $-0.260(-0.561$ to 0.101$)$ & 0.0665 \\
Anterior IAS $(\mathrm{cm})$ & $-0.339(-0.630$ to 0.034$)$ & 0.8988 \\
Gap length $(\mathrm{cm})$ & $0.023(-0.332$ to 0.372$)$ & 0.9240 \\
Radial angle of the defect & $0.017(-0.337$ to 0.367$)$ & 0.1223 \\
Intact sphincter $(\mathrm{n}=16)$ Continence score vs & $-0.402(-0.755$ to 0.132$)$ & 0.8287 \\
Anterior EAS $(\mathrm{cm})$ & $-0.058(-0.550$ to 0.462$)$ & 0.4443 \\
Anterior IAS $(\mathrm{cm})$ & $-0.205(-0.646$ to 0.337$)$ & \\
Gap length $(\mathrm{cm})$ &
\end{tabular}

EAS: external anal sphincter; IAS: internal anal sphincter 
or 30-s squeeze pressure and anterior EAS and IAS length on 3-DAUS in the sphincter defects group (Tables 5, 6).

\section{Interobserver variability}

As shown in Table 7, intraclass correlation coefficients (average) for evaluations by the two blinded surgeons ranged from 0.918 to 0.981 in the sample of 31 participants (including patients with fecal incontinence symptoms and controls). Thus, interobserver agreement was classified as very good for all measurements.

\section{DISCUSSION}

Ultrasonography has become the gold-standard method for assessment of anal canal anatomy. Two-dimensional ul- trasonography is limited by the single plane of view and can be used to measure the extent of the defect circumferentially

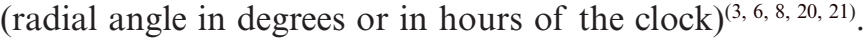
The recent development of 3-DAUS using $360^{\circ}$ field-of-view transducers provides a topographical overview of anal canal anatomy and allows measurement of length, thickness, area of sphincter defect in the sagittal and coronal planes, and volume of sphincter damage ${ }^{(18,22,24,27)}$. Few studies have reported on the contribution of this modality in the evaluation of anal canal anatomy in patients with fecal incontinence ${ }^{(18,}$ 24, 26, 27). In previous reports, we have demonstrated the asymmetrical shape of the anal canal and compared anal sphincter positions and lengths between the sexes ${ }^{(18)}$ The anterior EAS and the IAS have been described as shorter in women, producing a longer gap with a less resistant upper anal canal

TABLE 5. Correlation between anterior external anal sphincter and anal pressure measurements on anorectal manometry in patients had sphincter defects (EAS defect plus combined EAS and IAS defects) and had intact sphincters

\begin{tabular}{lcc}
\hline Anorectal manometry & r (95\% confidence interval) & $P$ \\
\hline EAS defect plus EAS + IAS defect $(\mathrm{n}=33)$ Anterior EAS $(\mathrm{cm})$ vs & & 0.0445 \\
$\quad$ Resting pressure $(\mathrm{mmHg}) *$ & $0.405(-0.000$ to 0.696$)$ & 0.5888 \\
$\quad$ Maximum squeeze pressure $(\mathrm{mmHg})$ & $0.113(-0.306$ to 0.496$)$ & 0.3498 \\
$\quad$ Squeeze pressure for $30 \mathrm{~s}(\mathrm{mmHg})$ & $0.214(-0.252$ to 0.600$)$ & 0.6092 \\
Intact sphincter $(\mathrm{n}=16)$ Anterior EAS $(\mathrm{cm})$ vs & $-0.149(-0.640$ to 0.428$)$ & 0.9937 \\
$\quad$ Resting pressure $(\mathrm{mmHg})$ & $0.002(-0.541$ to 0.544$)$ & 0.5636 \\
$\quad$ Maximum squeeze pressure $(\mathrm{mmHg})$ & $-0.169(-0.652$ to 0.411$)$ & \\
Squeeze pressure for $30 \mathrm{~s}(\mathrm{mmHg})$ &
\end{tabular}

$*(P<0.05)$; EAS: external anal sphincter; IAS: internal anal sphincter

TABLE 6. Correlation between anterior internal anal sphincter and anal pressure measurements on anorectal manometry in patients had sphincter defects (EAS defect plus combined EAS and IAS defects) and had intact sphincters

\begin{tabular}{lcc}
\hline Anorectal manometry & r (95\% confidence interval) & $P$ \\
\hline EAS defect plus EAS + IAS defect $(\mathrm{n}=33)$ Anterior IAS $(\mathrm{cm})$ vs & & 0.0165 \\
$\quad$ Resting pressure $(\mathrm{mmHg}) *$ & $0.474(0.085$ to 0.738$)$ & 0.5832 \\
Maximum squeeze pressure $(\mathrm{mmHg})$ & $0.115(-0.304$ to 0.497$)$ & 0.1629 \\
$\quad$ Squeeze pressure for 30 s (mmHg) & $0.316(-0.147$ to 0.665$)$ & 0.5607 \\
Intact sphincter $(\mathrm{n}=16)$ Anterior IAS $(\mathrm{cm})$ vs & $-0.170(-0.653$ to 0.410$)$ & 0.8354 \\
$\quad$ Resting pressure $(\mathrm{mmHg})$ & $-0.061(-0.584$ to 0.498$)$ & 0.9192 \\
Maximum squeeze pressure $(\mathrm{mmHg})$ & $0.029(-0.521$ to 0.563$)$ & \\
Squeeze pressure for 30 s $(\mathrm{mmHg})$ & &
\end{tabular}

EAS: external anal sphincter; IAS: internal anal sphincter

TABLE 7. Intraclass correlation coefficients for parameters of anal canal anatomy on 3-Dimensional anal ultrasonography measurements

\begin{tabular}{lcc}
\hline 3-DAUS measurements & ICC $(\mathbf{n}=118)$ & 95\% CI \\
\hline Anterior EAS length & 0.918 & $0.330-0.983$ \\
Anterior IAS length & 0.940 & $0.753-0.985$ \\
Posterior IAS length & 0.962 & $0.847-0.991$ \\
Posterior EAS+PR length & 0.958 & $0.829-0.990$ \\
Gap length & 0.982 & $0.930-0.996$ \\
Radial angle of the defect & 0.973 & $0.889-0.993$ \\
\hline
\end{tabular}

EAS: external anal sphincter; IAS: internal anal sphincter 
wall, predisposing to fecal incontinence, especially following vaginal delivery or anorectal procedures ${ }^{(14,18)}$.

In this study, we evaluated changes in the anatomy of the anal canal in symptomatic women after vaginal delivery and assessed potential correlations with continence scores and anorectal manometry pressures. We also included a control group of asymptomatic nulliparous subjects for comparison with symptomatic patients without sphincter defects in terms of anal muscle length. Using 3-DAUS, we identified sphincter defects in $67 \%$ of incontinent females with previous vaginal delivery, and found that these subjects had a significantly shorter anterior EAS and IAS and longer gap than women without defects, whereas women with a history of vaginal delivery and intact sphincters had a significantly shorter anterior EAS and longer gap than nulliparous women. This is an interesting finding, as we understand that vaginal delivery may change the anal anatomy, making the anal canal more asymmetrical and causing loss of resistance. Perhaps, over time, other risk factors (such as anorectal and colorectal surgery and clinical conditions) may have an additive effect and lead to the subsequent development of continence disorders. Oberwalder et al. reported that $71 \%$ of women with late-onset fecal incontinence after vaginal delivery had occult sphincter defects ${ }^{(15)}$.

Although our results show no differences in continence scores between patients with and without symptoms and no correlation between muscle length, scores, and squeezing pressure as measured by anorectal manometry, we did observe a positive correlation between resting pressure and anterior EAS and IAS length on 3-DAUS in patients who had sphincter defects. These results are consistent with those of previous studies ${ }^{(2,22)}$, but all these measurements are relevant to therapeutic decision making, as ultrasound can differentiate between incontinent patients with intact anal sphincters and those with sphincter lesions, as well as associate anal pressures and symptoms, providing additional value to select patients for different treatment modalities. Fecal incontinence is multifactorial; different mechanisms are involved ${ }^{(12)}$ and patients with fecal incontinence and intact sphincter may have muscle degeneration, atrophy, or pudendal neuropathy ${ }^{(19,23,25)}$. Ultrasound can identify clinically occult anal sphincter injuries following vaginal delivery ${ }^{(8,16)}$.

In this study, we also measured 30 -s voluntary squeeze pressure by manometry. These measurements provide a better evaluation of striated muscles, and patients with intact sphincter had a significantly higher 30 -s voluntary squeeze pressure. Previous studies have shown significantly higher mean maximal squeeze pressures in patients with intact muscles ${ }^{(22,24,26)}$.

To reduce the number of parameters analyzed, the current study focused on muscle length and gap length in patients with a history of previous vaginal delivery. Patients with a history of surgery and those with sphincter lesions involving the whole length of the anal canal were excluded.

We performed 3-DAUS in automatic scan mode, without moving the probe. In this modality, images are captured along the proximal-distal axis of the anal canal by moving two crystals on the extremity of a stationary transducer. All measurements were obtained accurately, without any interference from probe movement, and our results demonstrated very good interobserver variability due to the simplicity of length measurements, as previously described in the literature ${ }^{(9,13,14)}$. Volumetric measurements were not obtained, since they are limited by methodology, which consists of measuring the area of the anal sphincter in successive images, hindering determination of the exact lateral, proximal and distal limits of the muscles ${ }^{(17)}$.

Our study was limited by the small sample size and by the heterogeneity of the incontinence group, which included primiparous and multiparous women. Furthermore, our data did not include detailed clinical information on deliveries.

\section{CONCLUSIONS}

Fecal incontinence symptoms did not correlate directly with anal pressures and anal sphincter anatomy changes (sphincter length, radial angle) in women with a history of vaginal delivery, but women with sphincter defects have shorter anterior EAS and IAS and a longer gap and there were correlations with lower resting pressure. Additionally, women with previous vaginal delivery and no sphincter injury do exhibit changes in anterior anal canal anatomy: the EAS is shorter and the gap is longer than in nulliparous women. On the basis of this study, it seems rational that a comprehensive evaluation be offered to all patients with symptomatic fecal incontinence so as to enable identification of anatomic changes and quantify function to select patients for anal repair. Three-dimensional anal ultrasonography was found to be a reliable method for measurement of anal structures, especially muscle length. 
Murad-Regadas SM, Dealcanfreitas ID, Regadas FSP, Rodrigues LV, Fernandes GOS, Pereira JJR. Alterações na anatomia do esfíncter anal se correlacionam com a função anal em mulheres com história de parto vaginal? Arq Gastroenterol. 2014,51(3):198-204.

RESUMO - Objetivos - Avaliar a anatomia do esfíncter anal usando ultra-sonografia tridimensional (3D-US) em mulheres incontinentes com parto vaginal, correlacionar os achados anatômicos com sintomas de incontinência fecal e, determinar o efeito do parto vaginal sobre a anatomia e função do canal anal. Métodos - Mulheres com sintomas de incontinência fecal e história de parto vaginal foram avaliadas com escore de Wexner, manometria e 3D-US. Um grupo controle constituído por nulíparas assintomáticas foi incluído. Pressão de repouso, o ângulo radial do defeito e o comprimento do esfíncter anal externo (EAE), o esfíncter anal interno anterior e posterior (EAI), o EAE + músculo puborretal e o gap foram medidos e correlacionados com escore. Resultados - Das 62 mulheres, 49 apresentaram sintomas de incontinência fecal e 13 eram nulíparas assintomáticas. Vinte e cinco tinham defeitos EAE, 8 haviam defeito combinado EAS e IAS, 16 tinham esfíncteres intactos e escores de continência foram semelhantes. Indivíduos com defeitos do esfíncter tinha um menor EAE e EAI anterior em relação as mulheres sem defeitos. Aquelas com um parto vaginal e esfíncteres intactos tinham um menor EAE anterior em relação as mulheres nulíparas. Evidenciou-se correlações entre a pressão de repouso e a medida do EAS anterior e IAS em pacientes com defeitos do esfíncter. Conclusões - Sintomas de incontinência fecal não se correlacionou com as pressões anais e alterações anatômicas do esfíncter anal, mas as mulheres com defeitos do esfíncter têm menor EAS anterior e IAS e uma gap maior e houve correlações com menor pressão de repouso.

DESCRITORES - Incontinência fecal, ultrassonografia. Canal anal, fisiologia. Parto normal.

\section{REFERENCES}

1. Altmann DG. Pratical statistics for medical research. London: Chapman \& Hall 1991.

2. Bordeianou L, Baxter NN, Lee KY, Lowry A, Mellgren A, Parker S, Rockwood T. Anal resting pressures at manometry correlate with the Fecal Incontinence Severity Index and with presence of sphincter defects on ultrasound. Dis Colon Rectum. 2008; 51:1010-1014.

3. Deen KI, Keighley MR, Kumar D, Olliff J, Williams JG. The prevalence of anal sphincter defects in faecal incontinence: a prospective endosonic study. Gut. 1993; 34:685-688.

4. De Leeuw JW, Auwerda HJ, Bac DJ, Struijk PC, Wallenburg HC, Vierhout ME. Anal sphincter damage after vaginal delivery: relationship of anal endosonography and manometry to anorectal complaints. Dis Colon Rectum. 2002; 45:1004-1010.

5. Faltin DL, Boulvain M, Floris LA, Irion O, Otero M, Petignat P, Sagalli MR. Women's health 18 years after rupture of the anal sphincter during childbirth: I Fecal incontinence. Am J Obstet Gynecol. 2006; 194:1255-1259.

6. Felt-Bersman RJ, Cuesta MA, Koorevaar M, Strijers RL, van Baren R. Unsuspected sphincter defects shown by anal endosonography after anorectal surgery. A prospective study. Dis Colon Rectum. 1995; 38:249-253.

7. Jorge JMN, Wexner SD. Etiology and management of fecal incontinence. Dis Colon Rectum. 1993; 36:77-97.

8. Karoui S, Denis P, Koning E, Leroi AM, Savoye-Collet C. (1999) Prevalence of anal sphincter defects revealed by sonography in 335 incontinent patients and 115 continent patients. AJR Am J Roentgenol. 1999; 173:389-392.

9. Knowles AM, Knowles CH, Lunniss PJ, Scott SM. Effects of age and gender on three-dimensional endoanal ultrasonography measurements: development of normal ranges. Techniques in Coloproctology. 2008; 12:323-329.

10. Law PJ, Bartram CI, Kamm MA. Anal endosonography in the investigation of faecal incontinence. Br J Surg. 1991; 78:312-314.

11. Lewis SJ, Heaton KW. Stool form scale as a useful guide to intestinal transit time. Scand J Gastroenterol. 1997; 32:920-924

12. Menees SB, Chey WD, Fenner DE, Saad RJ, Smith TM, Xu X. Factors associated with symptom severity in women presenting with fecal incontinence. Dis Colon Rectum. 2013; 56:97-102.

13. Murad-Regadas SM, Barreto RG, Holanda EC, Oliveira L, Regadas FSP, Rodrigues LV. The role of three-dimensional anorectal ultrasonography in the assessment of anterior transsphincteric fistula. Dis Colon Rectum. 2010; 53:10351040.

14. Murad-Regadas SM, Buchen G, Fernandes GO, Kenmoti VT, Regadas Filho FSP, Regadas FS, Rodrigues LV. Effect of vaginal delivery and ageing on the anatomy of the female anal canal assessed by three-dimensional anorectal ultrasound. Colorectal Dis. 2012; 14:1521-1527.
15. Oberwalder M, Baig MK, Cotman K, Dinnewitzer A, Efron J, Nogueras JJ, Thaler K, Weiss EG, Vernava AM. 3rd Wexner SD. The association between late-onset fecal incontinence and obstetric anal sphincter defects. Arch Surg. 2004; 139:429-432.

16. Oberwalder M, Connor J, Wexner SD. Meta-analysis to determine the incidence of obstetric anal sphincter damage. Br J Surg. 2003; 90:1333-1337.

17. Olsen IP, Augensen K, Kiserud T, Wilsgaard T. Three-dimensional endoanal ultrasound assessment of the anal sphincters: reproducibility. Acta Obstet Gynecol Scand. 2008; 87:675-681.

18. Regadas FSP, Barreto RGL, Lima DMR, Murad-Regadas SM, Regadas Filho FSP, Silva FR, Souza MHLP. Anal canal anatomy showed by three-dimensional anorectal ultrasonography. Surg Endosc. 2007; 21:2207-2211.

19. Roig JV, Alós R, Buch E, Hinojosa J, Lledo S, Solana A, Villoslada C. Prevalence of pudendal neuropathy in fecal incontinence: results of a prospective study. Dis Colon Rectum. 1995; 38:952-958.

20. Sultan AH, Bartram CI, Hudson CN, Kamm MA, Thomas JM. Anal sphincter disruption during vaginal delivery. N Engl J Med. 1993; 329:1905-1911.

21. Sultan AH, Bartram CI, Kamm MA, Nicholls RJ, Talbot IC. Anal endosonography for identifying external sphincter defects confirmed histoligically. Br J Surg. 1994; 81:463-465.

22. Wasserberg N, Kaufman HS, Mazaheri A, Petrone P, Tulchinsky H. Three-dimensional endoanal ultrasonography of external anal sphincter defects in patients with faecal incontinence: correlation with symptoms and manometry. Colorectal Dis. 2011; 13:449-453.

23. West RL, Briel JW, Dwarkasing S, Hansen BE, Hussain SM, Kuipers EJ, Schouten WR. Can three-dimensional endoanal ultrasonography detect external anal sphincter atrophy? A comparison with endoanal magnetic resonance imaging. Int J Colorectal Dis. 2005; 20:328-333.

24. West RL, Felt-Bersma JF, Hansen BE, Kuipers ER, Schouten WR. Volume measurements of the anal sphincter complex in healthy controls and fecal-incontinent patients with a three-dimensional reconstruction of endoanal ultrasonography images. Dis Colon Rectum. 2005; 48:540-548.

25. Williams AB, Bartram CI, Halligan S, Kamm MA, Kmiot WA, Malouf AJ. Assessment of external anal sphincter morphology in idiopathic fecal incontinence with endocoil magnetic resonance imaging. Dig Dis Sci. 2001; 46:1466-1471.

26. Williams AB, Bartram CI, Spencer JA. Assessment of third degree tears using three-dimensional anal endosonography with combined anal manometry: a novel technique. BJOG. 2012; 109:833-835.

27. Williams AB, Bartram CI, Halligan S, Kmiot WA, Nicholls RJ, Spencer JA. Anal sphincter damage after vaginal delivery using three-dimensional endosonography. Obstet Gynecol. 2001; 97:770-775. 